\title{
Study on the Practice Model of Social Work
}

\author{
Shaozhen $\mathrm{Yu}^{1, *}$, Weifeng $\mathrm{Li}^{2}$,Dong Liang ${ }^{3}$ \\ ${ }^{1}$ School of Political Science and Law University of Jinan, Shandong 250022, China; \\ ${ }^{2}$ School of Political Science and Law University of Jinan, Shandong 250022, China; \\ ${ }^{3}$ School of Political Science and Law University of Jinan, Shandong 250022, China. \\ *Corresponding author. Email:2461904290@qq.com
}

\begin{abstract}
In the post-information society, with the rapid development of science and technology, the increasingly fine social division of labor, the population movement circle becomes more extensive. In this process, the traditional family problem swelled, the group's dilemma gradually revealed, and thus, in order to solve a sudden series of family, community school and even social problems, the social demand for professional social work services surges. But in fact, the current lack of social work talents, specialized service level is low, it is difficult to solve a series of problems and dilemmas efficiently.Therefor, it is urgent for institutions and society to work together to establish a scientific and professional model of professional social work practice, breaking through the limitations and short board of training of social work personnel in the past, training the applied, timely and comprehensive talents of the profession, so as to realize the professionalization of social work and promote the healthy development of society.
\end{abstract}

Keywords: Social Work Internship Cognition; Internship Model; Social Work Talents

\section{INTRODUCTION}

The Party and the government attach great importance to the training and development of social work talents. At the Sixth Plenary Session of the 16th Central Committee in 2006, the Party and the Central Government made the decision for the first time to train the social work talents. In 2010, the CPC Central Committee and the State Council again pointed out the needs of social workers at this stage and the objectives of classification training in the Outline of the National Medium- and Long-Term Talent Development Plan (20102020). School is the petri dish of social workers, how to cultivate qualified social workers in the existing training programs, really expand the social work team,and effectively carry out social work, has become the top priority of many colleges and universities. At present, the academic circles are based on different starting points, and the model of social work internship is different. From the point of view of relying on the main body, it is generally divided into several models based on individual students, institutions, and NGOs."Internship Teaching Center" model, around the social work department of the institutions, to carry out or build or hire or the joint way of institutions to solve the problem of lack of professional social work internships, with the help of local governments and international nongovernmental organizations, social welfare institutions as a social work internship base of the "government support, use of external forces" model, "internal training" model emphasizes people-oriented, based on the heart, and constantly enhance the professional ism of social work teaching and practice model.so,we should further look at social work institutions and explore the feasibility of student professional internships to enhance the professionalism of social work services in institutions. Based on the above research and its own foundation, it will focus on the origin, mode and participation of the institutions in social work professional internship sourm.

\section{THE DEVELOPMENT PROFESSIONAL INTERNSHIP}

OF

Social work internship, as a link between social work education and practice, with the twists and turns of social work professional development ups and downs, but also exudes the incomparable mystery and superiority of other professions.

\subsection{Initial: Practice activities}

The welfare thought, humanitarianism and Christian spirit of Europe and America gave birth to a profound cultural soil for the birth of social work, which originated in the Western world, and was established and developed in China in the first half of the 20th century.China's early social work more to save the survival of patriotic social activities, there is no professional internship. In 1925, Yanjing University established the Department of Sociology and Social Services, which is regarded as the beginning of China's professional social work major.

\subsection{Start: Internship Spout}

In 1987, the latest revision of the Directory and Introduction to the Undergraduate ProfessionalSin of Social Sciences in General Higher Education institutions was published. In 
1989, the first batch of schools, represented by Peking University, enrolled undergraduates in social work and management. In the 1970 s, the social work major, together with other majors, ushered in the "townshipization" stage, and some schools that basically did not have the conditions of teachers and other school-running conditions also set up an undergraduate major in social work. This not only promoted the substantial increase in the number of social work enrollment, but also promoted the improvement of social work education curriculum, at the same time, institutions began to seek integration with social services, social work internships gradually began.

\subsection{Development: Internship Cognitive Bias}

After the reconstruction of social work profession, professional internship swells up rapidly, but also faces the risk of going astray. In any department, the role of student internships is not separated from the students themselves, or even for beginners who have not yet done so in the field of social work practice, in contrast, social worker interns become the same administrative staff as other professional interns, responsible for day-to-day work. Students have very few opportunities to use professional value concepts and methodological skills to work, the professional gold content is very low, the effectiveness of internships and students' internship expectations are very different. Although the safety internship reduces the student accident rate, but also reduces the student's enthusiasm and quality of internship.

\section{INTERNSHIP PROGRAMME}

From the participation of the main body, social work professional internship needs schools, social organizations (or other social work services, institutions) students and even the service object of the Quartet participation, any of the loopholes will affect the efficiency and quality of internship, the following will be mainly from the internship objectives, process, the results of the institutions of social work professional internship model.

\subsection{Identify the first training objectives}

For the length of professional internship in social work, the basic number of undergraduate social work professional internships is generally required in foreign countries to be 800-1200 hours, while domestic colleges and universities require 400-800 hours of school hours.

However, in the process of practical training, the requirements of colleges and universities to implement lax, resulting in insufficient internship time, the problem of loose internship. To this end, the primary goal of clear social work professional internship is particularly important, whether to practice the practice or to ensure that students low error rate, to ensure safety as the goal. The field of social work service is different from other general areas, its special service groups need social workers have very high physical and psychological quality, whether the goal of college internship training is based on improving students' general education, or training elite social workers, based on different goals, the quality of student internship will also be very different. This will not only lead students in the internship to the practical attention is not high, understanding is not clear, practice is not deep problems, but also will increase the difficulty of employers, and then appear the current social work professional personnel training and the real needs of the dislocation between the problem.

\subsection{Professional process supervision}

Supervision, generally by the more experienced social workers, in the student internship process, responsible for timely recording of problems and communication with students, to guide and enhance the professional service of students. Whether it is one-to-one or one-to-many, many-tomany forms of supervision, supervision is an indispensable role in social work internships.

Theoretically, in the process of social work internship, interns receive the dual guidance of internship supervision and the leadership of the internship unit. However, in the actual teaching work, the internship guidance teachers sent by the institutions also have the teaching task, and must not have the same supervision qualifications and experience, which results in even if students participate in the internship, it will not necessarily get full supervision and guidance, but more is the direct leadership of the internship unit, this will cause certain confusion for students from the transition stage of the institution to the internship institutions, but also reduce the professional and social work of social work and their social work service standards.

\subsection{Effectiveness assessment}

The evaluation of the effectiveness of social work internships, i.e., a series of performances such as professional attitude and ability during the internship of students, such as a scale, feedback form, or other means. In the process of social work practice, supervision plays a guiding role, timely guidance and criticism, but after the internship, the internship unit should work with the supervision according to the characteristics of the unit's service population to establish an adaptive assessment mechanism, rather than just according to attendance rate and other forms of assessment indicators, the student's internship effectiveness of the authentic assessment, targeted points out the students' professional awareness and service skills loopholes, in order to truly grow in practice, and constantly improve the social work professional level of beginners. 


\section{THE SUBJECT OF PARTICIPATION}

A complete model of social work internship, cannot be separated from the participation of multi-party personnel, but also cannot be separated from the close cooperation of the internship base and multi-party financial support.

\subsection{Participating in the internship}

The practice of social work is not only the student's job, but also the teacher's participation.

\subsubsection{Teacher's institutional division of labor and professional guidance}

The professional ability of teachers directly affects the degree of professionalization of student internship, student internship should be familiar with the professional employment of personnel responsible for guiding and answering students' doubts. But at present, in the employment guidance education part of our country, the division of teachers is unclear, not only makes the task of scientific research, teaching teachers heavy, but also reduces the interest and quality of students' internships, on the other hand, there are many cases of reference and learning.

Take the Master of Social Work program at The University of North Carolina at Church Hill as an example ,the students of the program have three guidance teachers, respectively, similar to our university tutors, counselors and employment guidance teachers, the only difference is that the three are by scientific research, management, practical fields of experts, each of which performs their duties, cooperate with each other, but will never have a situation of one person taking into account three jobs. Clear division of teachers should be the top priority of social work professional internship, and then do a good job in the training of students.

\subsubsection{Students' classification training and professional internship}

Depending on the training objectives, the content of student participation in the internship varies from person to person. This requires that the internship of social work professional cannot be arranged with other majors in general at the end or near graduation, but from the moment of entry into the school, the school curriculum and off-campus internship should be carried out simultaneously, full-time students in 4 years of study and practice, gradually clear areas of expertise, set a clear employment objective.

For example, the training objectives of the Master of Social Work Program at the University of North Carolina at Church Hill, USA, range from ethical values to service cases, are divided into 7 specific targets, progressive layer by layer, and provide students with three research directions to choose from, from self, others to the management community, the research direction to maintain progressive research direction while also realizing the original intention of student classification training. At the same time, the curriculum takes into account general knowledge and special ity, but also takes into account the characteristics of social work in schools and the corresponding social needs. Social work services are widely available, and institutions should train students based on the school's history, teacher advantages and professional experience in social work to train students and build social work research and practical teams.

\subsection{Internship Base}

On the basis of the professional ism, finding a matching internship base is an important way to implement the professional skills of students in social work, but it is not easy.

At present, the number of social work institutions has increased significantly, but the number of internship bases with professional internship supervision and skills is far from meeting the requirements of social work professional internships in colleges and universities. So in reality, most social work internships are not a show of demand, but because of the simple, "will find an institution to practice." The choice of the internship base should consider whether the objectives of the internship institutions are consistent with the objectives of the professional training, whether there is a clear management and service mechanism, whether there is scientific equipment and the institution itself can maintain a healthy operation, and not blindly will be on the will.

\subsection{Internship funds}

At present, the college social work professional education has its own strengths, each has a short, but the funding has become a constraint on the quality of internships a major hidden danger, is helpless, but not no way to go.

Whether it is the connection with the actual base, the employment of trainee teachers and even the cost of students outside the school, are far more than the cost of classroom teaching, indeed to social work internships bring certain constraints. However, the school is not only a talent training base, but also the source of wealth creation, should open up the creation, constantly break the constraints of 规 traditional management ideas, break through the simple acceptance of financial subsidies, alumni donations and other sources of funding, innovative research funding allocation ratio, further clarify the cost of internship, appropriately raise internship tuition fees and ensure reasonable fees, not due to financial reasons caused by social work talent sandwich. 


\section{CONCLUSION}

As Mr. Wang Sibin said, china is the traditional social work and professional social work coexisting situation. On the one hand, China's historical tradition and administrative system determine the necessity of traditional social work, on the other hand, the development of professional social work makes up for the lack of the former and must be embedded in it and seek common development. The development of social work practice in colleges and universities should not be based on the traditional system, but the perfect integration of tradition and modernity, linking schools and out-of-school, related students and majors, pay attention to the development of social work internship education.

\section{ACKNOELEDGMENT}

This paper is one of the series of achievements of "Innovation and Practice of Talent Training Model" of the Outstanding Social Workers" in 2018, shandong University Teaching Reform Research Project, and thank you for supporting the project in this article!

\section{REFERENCES}

[1] Wei Shuang. Review and Reflection on the Practice Development of Social Work in China in the Last DecadeLiterature Study based on the Case of National Excellent Social Work J. Beijing University of Technology Journal (Social Science Edition), 2020, 20 (01): 47-53.

[2] Zhu Panling. School Social Work Practice Development Dilemma and Improvement Space . . Contemporary Youth Research, 2018 (05): 113-117.

[3] Sun Tangshui. The exploration of the social work practice model of the energy-enhancing type - take the internship in the Department of Social Work of Nanjing N College as an example. (J) Social Work, 2014 (01): 60-67153.

[4] Liu Wei. Reflections on the Practice Teaching of Social Work In the Context of Identification Deficiency. (J). Chinese Adult Education, 2013 (16): 166-168.

[5] Zhu Meihua. Experience and Inspiration of the Master's Program in Social Work in the United States - As an example of the University of Beika's Church Hill campus. Graduate Education Research, 2013 (01): 79-84.

[6] Zeng Huayuan.2003, Social Work Internship, Social Work Internship Course Handout
[7] Xiang Rong.2000, "China's Social Work Internship Education Model Re-Exploration", Yunnan Higher Education Research, No. 2. 